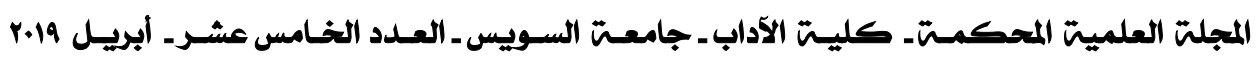

\title{
WAR, Containment and Animal Metaphors in Slave Narratives
}

\author{
Amal Ahmed Eassa Gami \\ Suez University
}




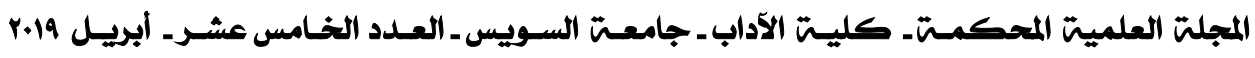

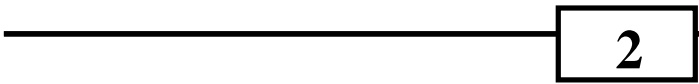




\section{Abstract:}

This study analyzes and compares between two slave narrative protagonists in their conceptualization of the metaphors of WAR, CONTAINMENT and ANIMAL. More specifically, it aims at revealing whether the cultural background of each writer affects her conceptualization of such concepts. The two ex-slave writers are Zana Muhsen, the protagonist of Sold: A Story of Modern-Day Slavery and Mende Nazer, the protagonist of Slave: My True Story. The study also investigates the emergent Self-Concept as revealed through the use of conceptual metaphors and how both protagonists are different from each other in their selfconceptualization. The study concludes a number of findings. First, it has been found that both ex-slave writers use WAR metaphors in such a way as to reflect how they conceptualize themselves as DEFEATED WARRIORS and how they conceptualize the whole slavery experience in terms of A LOST WAR. Second, the analysis of the data reveals that both protagonists use CONTAINMENT metaphors in a way that reflect cultural differences. Third, their use of the ANIMAL metaphors also reveals cultural differences between both protagonists. Finally, the study also concludes that the writers' use of the different conceptual metaphors helps in uncovering their Self-Concept.

Keywords: slave narrative, modern slavery, conceptual metaphor, territorality, WAR metaphors, ANIMAL metaphors, self-concept 


\section{WAR, Containment and ANIMAL Metaphors in Slave Narratives:}

The present study aims at investigating and comparing between the use of the conceptual metaphors (CMs) of WAR, CONTAINMENT, and ANIMALS as used by ex-slave protagonists in two slave narratives. Both autobiographies represent different forms of slavery. The first, first published in 1991, is entitled Sold: A Story of Modern-Day Slavery by Zana Muhsen and Andrew Crofts. It tells the story of an enforced child bride from Yemen who was sold into slavery by her own father through marriage (Sold, 2015). The second is entitled Slave: My True Story by Mende Nazer and Damien Lewis. First published in 2003, Slave tells the story of a young Sudanese girl who was sold into modern domestic slavery (Slave, 2015). According to The Global Slavery Index 2014, modern slavery is when "one person possessing or controlling another person in such as a way as to significantly deprive that person of their individual liberty, with the intention of exploiting that person through their use, management, profit, transfer or disposal" (GSI, 2014, p. 8). It encompasses different types: child trafficking, forced labour, sexual exploitation, criminal exploitation and domestic servitude (Modern slavery, 2015). Murphy (2014) claims that the "first-person narratives of human trafficking that have been published since 1991" act 
as "flesh and blood" examples of human enslavement in our modern time (p. 382). The "new slave narratives" of the $20^{\text {th }}$ and $21^{\text {st }}$ centuries have all come to be a documentation of evidence that slavery still exists in the world today (Murphy, 2014, p.383).

The study at hand attempts to provide answers for the following questions:

1- What are the differences and similarities between Zana Muhsen and Mende Nazer in their use of the CMs regarding the themes of WAR, CONTAINMENT and ANIMAL?

2- Do different types of modern slavery and the different cultural backgrounds of both protagonists affect the unconscious use of conceptual metaphors?

3- What self-concept is revealed through the use of conceptual metaphors of WAR, CONTAINMENT and ANIMAL? And how are both protagonists different from each other in their self-conceptualization?

The literature of CM in narrative discourse reveals that it is extensively studied in fictional narratives (e.g., Talmantaitö, 2008; Schirrmacher, 2017; Seddeek and Ehsan, 2017; Kurniawati et al., 2014; Walker, 2013; Singh, 2010; Yamina, 2016; Hernández, 1997) and in non-fictional narrative alike 
(e.g., Martens and Biebuyck, 2013; Arvay et al., 1999; Tally, 2016; Leslie, 2012; Golden and Lanza, 2013; Kromhout and Charles, 2013). Nonetheless, it has been observed that the literature of conceptual metaphors almost lacks studies that are concerned with studying conceptual metaphors in autobiographies, specifically in slave narratives. One example is Norman's (1993) study which examines how Frederick Douglass in his autobiography uses conceptual metaphor as a tool for expressing his deepest sentiments about his experience of slavery, his regained freedom and the freedom of black people in general. As a result of such shortcomings concerning the research of CM in slave narrative, the significance of the current study lies in that it sheds light on the use of CM in modern slave narratives as used by victims of a shocking truth about the modern world.

The present study adopts two theories. The first is Conceptual Metaphor Theory (CMT) (Lakoff and Johnson, 1980; 2003). CMT is launched by Lakoff and Johnson (1980) in which metaphor is modeled as a mapping from a conceptual source domain to a conceptual target domain. The second is McConnell \& Strain's 2007 framework of the Self-Concept in which they present the Self as comprised of "multiple selfaspects, each of which is comprised of a series of attributes" (p.57). 


\section{Method and Procedure}

The procedure used for data analysis consists of three main steps. The first is concerned with identifying and analyzing the different CMs of WAR, CONTAINMENT and ANIMAL in two slave narratives selected for data analysis based on the framework of Conceptual Metaphor Theory as set forth by Lakoff and Johnson (1980, 2003). The second is to compare between both protagonists in their use of such metaphors. The third is concerned with detecting and identifying the Self-Concept of the protagonists related to the metaphors identified based on McConnell and Strain's (2007) framework for identifying self-concept content and structure.

\section{Data Analysis}

This section analyzes the conceptual metaphors of WAR, CONTAINMENT and ANIMAL as used by Zana Muhsen in Sold and Mende Nazer in Slave. It is divided into three parts. The first is concerned with analyzing and comparing between Zana and Mende in their use of WAR metaphors. The second deals with analyzing and comparing between the protagonists in their use of CONTAINMENT metaphors. The third is concerned with analyzing and comparing between them in their conceptualization of ANIMAL metaphors. Moreover, the SelfConcept of each protagonist is also detected within each theme. 


\section{WAR Metaphors}

This category of metaphors includes related concepts such as WAR and FORCE source domains. It has been observed that such concepts as used by both protagonists; however, are unconsciously associated with the experience of slavery. For example, throughout the narrative, Mende uses these metaphors for specific purposes. The metaphor DEFENDING ONE'S FREEDOM OF BODY IS A LOST WAR is used by both narrators so as to present how they unconsciously conceptualize themselves as slaves. Moreover, Mende uses the metaphor THE RAIDER'S SEXTUAL DESIRE AS WAR/VIOLENCE/FORCE in a sense that implies the metaphor SLAVERY IS WAR which also presents how she conceptualizes herself as a slave.

In the following quote, Mende recalls how the Arab raider tries to rape her in the forest and how she tries to defend herself against him. Then, she is engaged in a religious selfschema in which she recalls her mother telling her that she shouldn't let any man ever touch her before marriage or else God would burn them in Hell. Such memory has driven her to "defend" herself and try to "fight him off the whole time":

... [H]e pushed his hand down between my legs. I felt a stabbing pain and I cried out, but he wouldn't stop. 
When I was younger, my mother had told me that I must not let any man touch my body before I was married. If I did, I would burn in Hell. But as I sat there clutching desperately onto the saddle with both hands, I couldn't defend myself. So I started to cry... For four or five hours we rode on like this, with me trying to fight him off the whole time. (Nazer \& Lewis, 2003, p.102-104)

The words "defend" and "fight" are drawn from the domain of WAR. They imply the metaphor DEFENDING ONE'S FREEDOM OF BODY IS WAR/A LOST BATTLE or GETTING CONTROL OVER ONE'S OWN BODY IS WAR. In such metaphor, Mende conceptualizes defending her own freedom as having a WAR against the raiders that she has to fight in order to be free.

Later on, the Arab raiders have taken all the captured children into a camp. The camp is divided into two tents: one for the girls and one for the boys. Among the boys was a boy called Ajok from Mende's village. Seeing the cut on Mende's lip, Ajok asks her if she has fallen off the horse. However, Mende replies that the Arab raider is the one who has done so. This makes Ajok become surprised to know that Mende has fought back the Arab man. This implies that Ajok as a potential 
male slave unconsciously thinks that fighting back a slave's own body is not a right thing to do. The word "fight" implies that DEFENDING A SLAVE'S OWN BODY IS A LOST WAR; a war that should not be launched in the first place.

Accordingly, two self-aspects and associated attributes emerge. First, Mende's recall of the raid and being captured by the Arab man and his constant attempts of sexual harassments as well as her use of the CM DEFENDING ONE'S FREEDOM OF BODY IS A LOST WAR suggest that Mende conceptualizes herself as a defeated warrior. Second, Mende's recall of the self-schema in which she recalls her mother telling her that as a Muslim she shouldn't allow any man to touch her presents her religious self as being sinful; however, she is a victim:

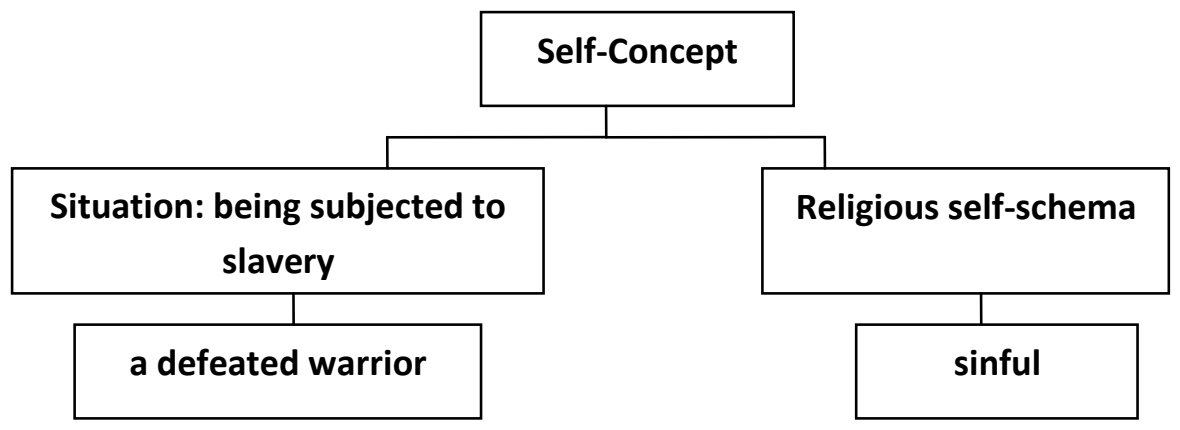

From the same view, Zana uses the metaphor DEFENDING ONE'S OWN FREEDOM OF BODY IS A LOST WAR:

Even though I was fighting it all the time, I knew I would have to give in in the end ... Abdul Khada was determined that I should submit and he wasn't a man 
that you could disobey forever. (Muhsen \& Crofts, 1991, p. 53)

After having discovered that she has been tricked and married without her knowledge, Zana decides that she has to "fight" Abdul Khada's desire that his son Abdullah, the so called husband, must have a sexual relationship with her. Unfortunately, Zana knows it too well that she can't win fighting all the time: Zana knows that she will "give in" and "submit" eventually and that Abdul Khada is not the kind of man whom she can defeat in A WAR. Accordingly, Zana, just like Mende, conceptualizes herself as a defeated warrior:

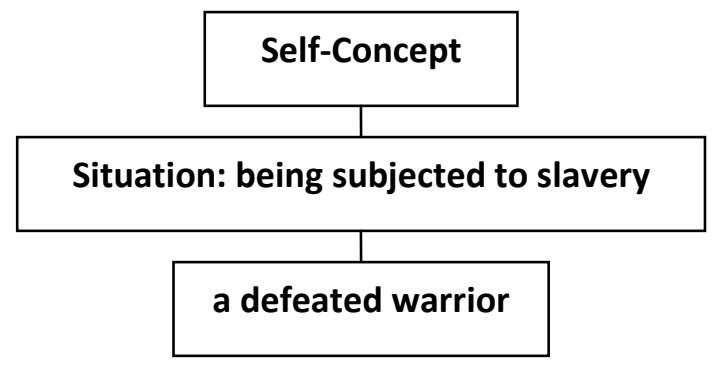

\section{CONTAINMENT Metaphors: Territorality}

The analysis of the data reveals that both protagonists use CONTAINMENT metaphors as a tool for uncovering their Self-Concept as well as how they conceptualize their slavery experience. However, their use of such metaphors reveals cultural differences. On the one hand, Mende uses the metaphor THE FOREST IS A CONTAINER paradoxically 
which reflects how she conceptualizes herself as a slave. Being a Nuba girl with the forest surrounds her, Mende's use of this metaphor reflects the environment in which she has been brought up and how such circumstances affect her unconsciously through the use of conceptual metaphors. On the other hand, Zana uses the CONTAINER image schema in a way that reflects: 1) how she is conceptualized in a maledominating society as in MORAL DANGER IS A CONTAINER and 2) how she conceptualizes her whole enslavement experience in terms of BEING IMPRISONED INSIDE A CONTAINER.

Mende unconsciously uses three parallel CONTAINER image schemas in which she marks the same territory, THE FOREST, as 1) as a place where the black Nuba villagers cherish and respect the lives of "black, hairy monkeys," 2) as the place where her slavery begins, and 3) as a place where she is between the devil and the deep blue sea. In the context of the raid and being captured as a slave, Mende recalls a mental image containing herself and her family sitting around the fire with her father telling them a story while the sky was "cloudless" and "clear." The story tells of "black, hairy monkeys" who used to live "in the forest." These "black" monkeys were sacred human-like monkeys because they had 
once been humans themselves. That was why the Nuba people never hunted or killed them:

After dinner, I sat around the fire with my mother and father, my brother Babo, our cow herder Ajeka and our uncles. My father was telling the story of why the Nuba never hunt monkeys ... Lots of black, hairy monkeys lived in the forest around our village, but we never hunted them. My father said that the reason they looked so human was that they had once really been people ... And that's why we never killed them. (Nazer \& Lewis, 2003, p.94)

Such mental image represents a significant event in Mende's life in which Mende recalls how first she has become a slave. It represents the last episode that Mende remembers about her life as a happy, free child with the presence of her family. It represents the last day Mende is having a real social life, a true identity and above all freedom. And choosing to unconsciously recall her father's story as the last episode of her free life suggests the significance of such episode. Mende unconsciously makes three parallel images based on the CONTAINER image schema. The first of these is included within her father's story about the "black, hairy monkeys" who used to live "in the forest." Within the PM, Mende uses the FOREST IS A CONTAINER metaphor. Here in this CM, 
Mende conceptualizes the FOREST in terms of A CONTAINER in which it has been prohibited to hunt or kill the "black, hairy monkeys." It is a CONTAINER of sacredness. The second image is included in the following quote in which Mende recalls the episode of the raid and being captured as a slave:

Then they started to take the younger girls and then, finally, the boys. A man came and grabbed Sharan. She cried out that she wanted to stay with me. But the man just slung her up onto his horse like a sack and rode off with her into the forest. (Nazer \& Lewis, 2003, p.100)

Ironically, the same forest is conceptualized as a source of pain and torture. The same territory is happened to be the place where it all begins: the same forest is where the raiders sling young girls up onto their horses and ride off with them to rape them and then capture them as slaves. Again, Mende conceptualizes THE FOREST in terms of A CONTAINER in which the raiders takes the children of Mende's village to rape and capture them as slaves. Nonetheless, within the same context, Mende uses the same metaphor in order to mark the same territory as a salvation of slavery and wishes to get back in time and be raped "in the forest" than to be captured there as a slave. Thus, the same conceptual metaphor of containment is 
used by Mende three times marking one territory as a place where animals are kept safe and holy, a place where young village girls are raped then captured as slaves, and a place where Mende wishes to be raped and perhaps left to die than to be a slave:

But thinking back on this now, if the guards had just raped me that night and left me behind in the forest, that would have been a good thing compared to what really happened to me. (Nazer \& Lewis, 2003, p.99)

Here in this quote, Mende's narrating "I" makes a comment in which she conceptualizes the same territory in terms of a salvation. After recalling the episodes of her father's story as well as of the raid, Mende as a narrator prefers to stay "in the forest" while being raped or even being killed to being captured and taken as a slave. In this sense, Mende's preference of being left behind IN the forest than being taken OUT and become a slave implies that she conceptualizes herself as being even inferior to those "black, hairy monkeys" in her father's story. Accordingly, the following self-aspect and an associated attribute emerge: 


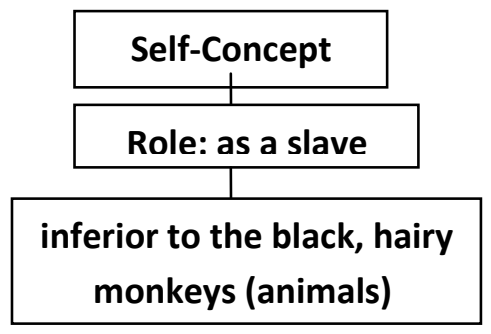

In like manner, Zana uses the metaphor MORAL DANGER IS A CONTAINER IN WHICH SHE IS IN in such a way as to reveal how she as a Yemeni girl is thought of by her father as a Yemeni male:

What we didn't realise was how badly Dad had taken it. He didn't come to the court with us, or offer to help out in any way, but to his Arab friends he talked about the shame of having his family name dragged into the courts, and his daughter branded as a thief. It seemed to confirm his fears that we were in moral danger and needed to be brought back onto the 'straight and narrow' path and taught to behave like good Arab women. (Muhsen \& Crofts, 1991, p. 11)

In this example, Zana recalls an incident in which Nadia, her younger and close sister, has been wrongly accused of stealing a ring from a shop in Birmingham. Zana recalls being alone in such a situation for their father was too ashamed to support his own family and be there for them. Instead, he used to scold his daughters for being immoral. In such context, Zana 
pictures how she and her sister are thought of by their father. She uses the metaphor MORAL DANGER IS A CONTAINER IN WHICH THEY ARE IN along with the metaphor MORALITY IS A ROAD/DESTINATION (e.g., "... to be brought back onto the 'straight and narrow' path) in order to conceptualize the male view of the Yemeni women in general. They are viewed by the male Yemeni society in Birmingham as immoral and should be brought back to the "narrow path" of morality. Actually, this "path" is happened to be a "narrow" one which implies that their father doesn't want them talk to anyone or to do the ordinary Birmingham daily social engagements, thus, restricting their freedom:

He started to become very strict with us... Every time I wanted to go out I had to make up stories for him ... He didn't like us wearing skirts that showed our legs ... He didn't like the people I was hanging round with, or the Sparkbrook area because of the men he believed were walking around the streets after dark. (Muhsen \& Crofts, 1991, p. 5)

It seems that their father as an Arab male has been suffering from a cultural conflict. As a result, Zana and Nadia's father has the authority to take them OUT of their so called IMMORALITY CONTAINER and send them back IN A PLACE/DESTINATION where he thinks is suitable for them. 
Additionally, Zana uses the metaphor BEING ENSLAVED IS BEING INSIDE A CONTAINER. This metaphor reveals how she feels imprisoned and deprived of her freedom that she eagerly seeks ways to get OUT:

All the time I was saying to my self, sooner or later Mum is going to find out about this, and she will get me out. (Muhsen \& Crofts, 1991, p. 50)

After knowing the real reason behind her travel to the Yemen and that her father has married her to his friend's son, Zana consoles herself by the idea of being taken OUT by her mother. This example reveals how Zana conceptualizes her ENSLAVEMENT in terms of being INSIDE A CONTAINER. Accordingly, the following self-aspect and associated attribute emerge:

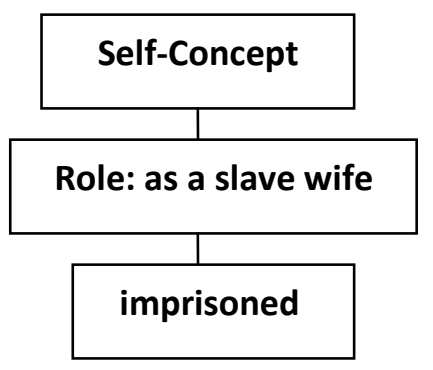

\section{ANIMAL Metaphors}

As for the theme of ANIMAL metaphors, they have special functions in both narratives. In one occasion, Mende conceptualizes the Arab raider in terms of AN ATTACKING WILD ANIMAL and herself in terms of A PREY in order to 
reveal how she conceptualizes being sexually harassed. In another example, Mende conceptualizes A MASTER-SLAVE RELATIONSHIP in terms of A WILD ANIMAL-PREY RELATIONSHIP. In so doing, Mende conceptualizes Rahab in terms of AN ATTACKING WILD ANIMAL, on the one hand, and conceptualizes herself in terms of A PREY, on the other. Both cases reveal Mende's conception of her own experience of slavery. However, Zana in Sold conceptualizes herself in terms of A PREY BEING CAUGHT IN THE MALE TRAP. Such metaphor reveals how Zana, a young Yemeni girl who has been living in Birmingham her whole life, conceptualizes the texture of the male-dominant Yemeni culture.

Within the context of the raid and being captured by one Arab raider, Mende recalls a visual image containing herself and the raider riding along a stony riverbed. Mende unconsciously conceptualizes herself as A PREY ANIMAL and the Arab raider who captured her as AN ATTACKING ANIMAL:

We were following a stony riverbed that wound through the forest. It was very uneven and dangerous, he explained, and he had to hold onto me tightly, to protect me. My breasts were small and tender, and he kept pawing at them. (Nazer \& Lewis, 2003, p.102) 
Thus, the verb "paws" suggests that the Arab raider is an animal that touches 'its prey' several times with its foot before attacking it. This metaphor entails yet another metaphor: SEXUAL BEHAVIOR IS ANIMAL BEHAVIOR. This means that being sexually desired and raped is not human. In other words, Mende in conceptualizing herself as A PREY, unconsciously uncover the idea that being raped is a way for depriving the young slave girl of part of their sense of humanity.

Similarly in another occasion, Mende uses another metaphor in order to conceptualize A MASTER-SLAVE RELATIONSHIP in terms of A WILD ANIMAL-PREY RELATIONSHIP:

Sometimes, Rahab would catch me daydreaming. I might be hiding in the bushes, staring at the gate leading out onto the street. She would watch me for a long time before I finally noticed her. Then she'd attack me. (Nazer \& Lewis, 2003, p.170)

Mende in this image conceptualizes Rahab as a WILD ANIMAL that is waiting for the right moment to "attack" its PREY. In other words, this image is inspired from a wild animal-prey relationship in which the wild animal always hides and waits for the right moment to attack its prey. Accordingly, 
the following self-aspect and associated attribute emerge from both examples:

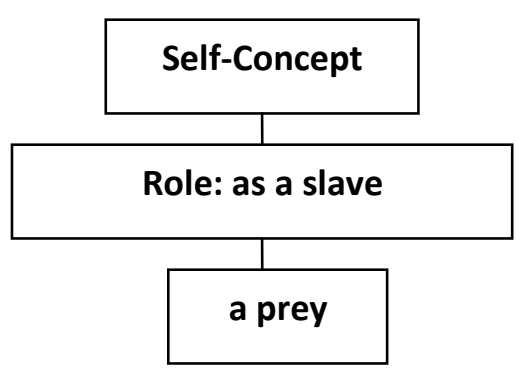

Likewise, Zana uses the metaphor YEMENI MEN ARE HUNTERS versus ZANA IS A PREY BEING CAUGHT IN THE MALE TRAP. Divided in twenty chapters, Sold includes a chapter entitled "Trapped." Throughout "Trapped," Zana is recalling how she has ended up as a slave wife without her knowledge. This very title implies how Zana pictures her real situation as a Yemeni girl in a male-dominating culture. Zana conceptualizes herself as A PREY who finds itself inside A TRAP plotted by her own father. In this context, Zana recalls how her father has plotted to send her from Birmingham where she has been living her whole life to the Yemen in a false holiday. Zana's father has managed to convince her to travel to the Yemen with Abdul Khada, a friend of his, to spend the holiday. In fact, her father has married her to Abdullah, the son of Abdul Khada, without Zana's consent or even her knowledge: 
... it was too late for anyone to be able to stop what was happening, I was already in their trap with no hope of escape. (Muhsen \& Crofts, 1991, p. 29)

Accordingly, the following self-aspect and associated attributes emerge:

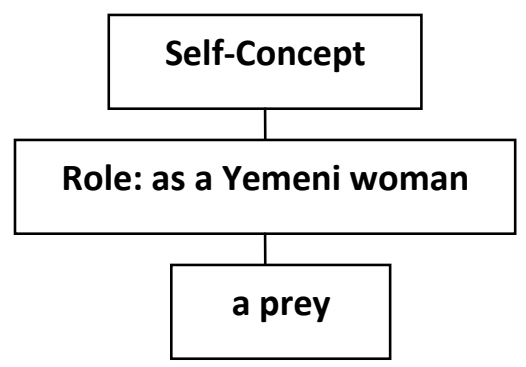




\section{Summary and Conclusion}

This study has investigated conceptual metaphors of WAR, CONTAINMENT and ANIMAL as used by Zana Muhsen, as an ex-slave Yemeni girl, and Mende Nazer, an exslave Sudanese girl when writing about their slavery experience. It has been observed that CM is used as a tool for revealing the protagonists' hidden views about their whole slavery experience, their Self-Concept and for revealing how cultural differences affect their conceptualization of some of the identified metaphors.

The main findings of the current study include the following:

1) Both protagonists with different cultural backgrounds who have experienced totally different forms of slavery conceptualize SLAVERY in terms of A LOST WAR. As a result, they both conceptualize themselves in terms of DEFEATED WARRIORS.

2) Although both protagonists use CONTAINMENT metaphors as a tool for uncovering their Self-Concept as well as how they conceptualize their slavery experience, each of them uses such metaphors in a way that reveal cultural differences. For example, Mende uses the metaphor THE FOREST IS A CONTAINER paradoxically which 
reflects how she juxtaposes herself with a black, hairy monkey. Thus, reflecting Mende's Nuba culture and surroundings. In the same manner, Zana uses the CONTAINER image schema in a way that reveals the nature of a male-dominating Yemeni culture as well as her conceptualization of herself.

3) ANIMAL metaphors are used by both protagonists differently. In the case of Mende, she conceptualizes the Arab raider in terms of AN ATTACKING WILD ANIMAL and herself in terms of A PREY. Mende also conceptualizes A MASTER-SLAVE RELATIONSHIP in terms of $A$ WILD ANIMAL-PREY RELATIONSHIP. In both metaphors Mende conceptualizes herself as A TAMED/DOMESTIC ANIMAL that reflects Mende's experience of domestic slavery. However, in the case of Zana, she conceptualizes herself in terms of A PREY BEING CAUGHT IN THE MALE TRAP. This metaphor functions as a tool for revealing the texture of the maledominant Yemeni culture.

4) However, not only does Zana conceptualize herself in terms of A PREY but also she conceptualizes herself as a Yemeni girl from Birmingham in terms of A WILD PREY which needs to be locked in a cage and be tamed. Drawn from the 
domain of HUNTING, Zana conceptualizes the Yemeni men represented by her father as A HUNTER and herself as A PREY BEING CAUGHT IN THE MALE TRAP. Additionally, Zana's use of the metaphor MORAL DANGER IS A CONTAINER IN WHICH SHE IS IN along with the ANIMAL metaphor implies that she conceptualizes herself in terms of A WILD PREY which needs to be tamed.

5) Finally, the analysis of the WAR, CONTAINER and ANIMAL metaphors reveals the Self-Concept of both protagonists. On the one hand, Mende's use of conceptual metaphors reveals that she unconsciously conceptualizes her Role as a slave in terms of being inferior to the black, hairy monkeys and a prey, her Situation self-aspect in terms of a defeated warrior and her Religious self-schema in terms of being sinful. On the other hand, Zana's use of conceptual metaphors reveals that she unconsciously conceptualizes her Role as a slave wife in terms of being imprisoned, her Role as a Yemeni woman in terms of a wild prey and her Situation self-aspect in terms of a defeated warrior. 


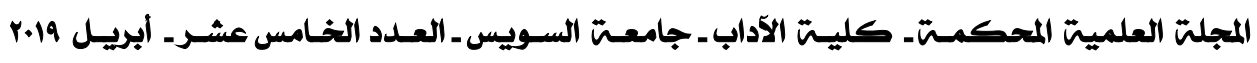

\section{Suggestions for Future Research}

Relying on the present study, the following suggestions for future research are made:

- Studying the effects of autobiographical memory on the use of conceptual metaphors in slave narratives

- Studying the effects of gender as social constructs from a Constructionist approach viewpoint on the use of conceptual metaphors in slave narrative

- Studying how the notion of social death is to be applied in slave narratives through the use of conceptual metaphors 


\section{References}

Arvay, M., Banister, E., Hoskins, M., \& Snell, A. (1999). Women's Lived Experience of Conceptualizing the Self: Implications for Health Care Practice. Health Care for Women International, 20:363-380. Retrieved from file:///C:/Users/hp/Downloads/073993399245665\%20(1) .pdf

Global Slavery Index. (2014). In The Global Slavery Index. Retrieved November 29, 2015, from http://www.globalslaveryindex.org/

Golden, A. and Lanza, E. (2013). Metaphors of culture: Identity construction in migrants' narrative discourse, Intercultural Pragmatics,10(2): 295-314. DOI 10.1515/ip-2013-0013

Hernández, L. P. (1997). A Cognitive Analysis of Paul Bowles's The Sheltering Sky. Cuadernosde Filología Inglesa, 3(2):259-278. Retrieved from

file://C:/Users/hp/Downloads/103831.pdf

Kromhout, R. and Charles, F. (2013). LIFE IS A JOURNEY: the source-path-goal schema in the videogames HalfLife, Heavy Rain, and Grim Fandango. Metaphor and the Social World, 3(1): 100-116. Retrieved from https://pure.uva.nl/ws/files/2082263/127260_kromhout_ and_Forceville_2013_Journey_metaphor_in_videogames _distributed_version_august_2013.pdf 
Kurniawati, Tallapessy, A., and Diana, S. (2014). A Study of Conceptual Metaphor in Suzanne Collins' The Hunger Games. PUBLIKA BUDAYA,3(2):73-77. Retrieved from https://media.neliti.com/media/publications/191224-ENa-study-of-conceptual-metaphor-in-suzann.pdf

Lakoff, G. and Johnson, M. (1980). Conceptual Metaphors in Everyday Language. The Journal of Philosophy, 77 (8): 453-486. Retrieved from

http://www.cse.buffalo.edu/ rapaport/575/F01/lakoff.joh nson80.pdf

Lakoff, G. and Johnson, M. (2003). Metaphors we Live by. University of Chicago Press: Chicago.

Leslie, C. (2012). Metaphor, Narrative and Reality in the Life Sciences, Via Panorâmica: An Electronic Journal of Anglo-American Studies, 113-131. Retrieved from http://ler.letras.up.pt/uploads/ficheiros/11655.pdf

Martens, G. and Biebuyck, B. (2013). Channelling figurativity through narrative: The paranarrative in fiction and nonfiction, Language and Literature,22(3): 249-262. DOI: 10.1177/0963947013489242

McConnell, A. R. and Strain, L. M. (2007). Content and Structure of the Self-Concept. In C. Sedikides \& S. Spencer (Eds.), The Self in Social Psychology (pp.5173). New York: Psychology Press. 
Murphy, L. T. (2014). The New Slave Narrative and the Illegibility of Modern Slavery, Slavery \& Abolition: A Journal of Slave and Post-Slave Studies, 36 (2), pp. 382405. DOI: 10.1080/0144039X.2014.977528. Retrieved from http://dx.doi.org/10.1080/0144039X.2014.977528

Norman, K. (1993). The Language Of Being And Metaphor Of Autobiography In Frederick Douglass's Narrative, REDEN,6: 21-28. Retrieved from

http://dspace.uah.es/dspace/bitstream/handle/10017/4842 /The \%20Language $\% 20$ of\%20Being\%20and\%20Metaph or\%20of\%20Autobiography\%20in\%20Frederick\%20Do uglass's $\% 20$ Narrative.pdf? sequence $=1$

Schirrmacher, B. (2017). Disturbing the Metaphor Performance and Medial Presence in the Fiction of Elfriede Jelinek and Günter Grass, Akademisk Kvarter,16:36-50. Retrieved from

file:///C:/Users/hp/Downloads/DisturbingTheMetaphor_ BeateSchirrmacher5.pdf

Seddeek, A. R. and Ehsan, A. (2017). Conceptual Metaphor In The Narrative And Visual Structures Of Suzanne Collins' The Hunger Games, International Journal of Management and Applied Science, 3(2):118-130. Retrieved from

http://www.worldresearchlibrary.org/up_proc/pdf/562148534482250-62.pdf 
Singh, S. (2010). Metaphor and the Postcolonial Novel (Master's Thesis). Retrieved from https://researchbank.rmit.edu.au/eserv/rmit:6406/Singh_ Exegesis.pdf

Slave, (2015). Damien Lewis. Retrieved from

http://www.damienlewis.com/index.php?option=com_co ntent $\&$ view $=$ article $\&$ id $=46 \&$ Itemid $=71$

Sold, (2015). Andrew Crofts. Retrieved from http://andrewcrofts.com/sold/\#

Talley, J. (2016). Moving from the margins: The role of narrative and metaphor in health literacy. Journal of Communication in Healthcare, 9(2):109-119. Retrieved from https://oro.open.ac.uk/46495/1/CIH195_ORO.pdf

Yamina, A. (2016). Analysis of Metaphor in Charles Dickens' Hard Times (Master's Thesis). Retrieved from https://bu.univ-ouargla.dz/master/pdf/AkermiYamina.pdf?idmemoire $=3976$ 